\title{
Reflexe nouzové výuky: distanční přednášky předmětu základy didaktiky
}

\author{
Karolina Duschinskáa, Radka High ${ }^{\mathrm{b}}$ \\ a Univerzita Karlova, Pedagogická fakulta, Katedra pedagogiky \\ b Univerzita Karlova, Pedagogická fakulta, Katedra psychologie
}

„S dobrou motivací se každá vzdálenost dá překlenout.“" Jane Austenová, Pýcha a předsudek (1797)

Neočekávaná situace, informační chaos a snaha co nejrychleji vybrat a zpracovat to nejpodstatnější; tyto charakteristiky jsou společné jak pro př́pravu tohoto textu, tak i pro události, které popisuje. $\mathrm{V}$ pomáhajících profesích $\mathrm{v}$ obdobné situaci hovoř́me o paralelním procesu, kdy je proces $\mathrm{z}$ jednoho vztahu přehráván do druhého vztahu. To, co se stane v jednom systému v jednom bodě v určitém čase, může být přehráno v jiném systému, jindy a s jinou osobou. ${ }^{2}$ Reflexe tohoto procesu pomáhá zvýšit uvědomění a ovlivnit situaci, proto jsme si tuto netradiční výzvu časopisu Pedagogická orientace přály a redakci tímto děkujeme za odvahu. Náhlé uzavření vysokých škol 11. března 2020 lze z didaktického hlediska chápat jako problémovou úlohu pro všechny zúčastněné, tj. jako průnik situace nové, nejisté a obtížné (Maňák \& Švec, 2003). Polya (1957, in Skalková, 2007, s. 159) definoval čtyři fáze heuristického procesu řešení problémové situace: (1) pochopení problému a podmínek, pojmenování daného a neznámého; (2) sestavení plánu - nejobtížnější část; (3) průběžné ověřování a zlepšování kroků; (4) systemizace metod, které je možno užít i v budoucnu. Podle těchto čtyř fází budeme strukturovat i náš text.

The distance is nothing when one has a motive.

2 Stanovská, B. Paralelní proces v supervizi: kvalitativní výzkum. Překlad a shrnutí článku: Hewitt Taylor, J., Rodway, R., Poole, S., \& Tyson, R. (2006). Parallel Process in Supervision: A qualitative investigation. European Journal for Qualitative Research in Psychotherapy, (1), 10-20. Dostupné z http://www.skaluvinstitut.cz/files/literatura/D_135.pdf 


\section{Problém a jeho pojmenování: nouzové distanční vyučování}

Po zavedení nouzového stavu ovlivnila pracovní náplň učitelů nová skutečnost, která byla komunikována jako požadavek na co nejrychlejší přechod na online výuku. Nebyl přitom znám způsob, jak to udělat. U učitelů vysokých škol se nejčastěji poukazovalo na zkušenosti s e-learningem z výuky studentů kombinované formy studia, případně z podpory prezenční výuky. Každá univerzita, fakulta, katedra i vyučující se však liší v možnosti a intenzitě využívání e-learningu. V krajním případě můžeme chápat e-learning jen jako úložiště výukových materiálů; druhý pól by pak představoval e-learning jako propracovaný systém navazujících výukových aktivit, který se tak stává prostředím pro online výuku. Každý vyučující tedy vstupoval do nouzové situace $\mathrm{z}$ jiných startovních podmínek. S odstupem se domníváme, že počáteční nasměrování na online výuku vedlo na straně pedagogů spíše k nejistotě. Hodges a kol. (2020) zformulovali 27. března text, kterým nastalou situaci vymezují proti online vyučování a specifikují ji jako tzv. Emergency Remote Teaching (ERT, lze přeložit jako „nouzové distanční vyučování“). ERT je vymezeno jako vyučování, které se v důsledku krizových okolností po určitý čas odehrává online, ačkoliv tak nebylo plánováno. Cílem je v co největší míře zpřístupnit výuku v krizové situaci, z toho vyplývá i nutnost rychlého výběru metod a technických řešení. Především u těch vyučujících, kteří nemají velké zkušenosti s online výukou, pak široká nabídka vzdělávacích platforem přináší spíše více komplikací než výhod. Autoři citovaného článku se zamýšlí také nad tím, jak hodnotit ERT a varují před srovnáváním s prezenční výukou nebo s propracovanými online kurzy. Hodnocení ERT by se mělo zaměřit na vlastní výukový proces v nouzových podmínkách.

Našimi východisky byly stejné požadavky na kvalitní výuku jako v běžné situaci, tj. především zajištění aktivního učení studentů na adekvátní úrovni kognitivní náročnosti. Neznámé nám byly prostředky a procesy, jak toho v distanční formě výuky dosáhnout.

\section{Sestavení plánu}

Příprava plánu výuky probíhala ve dvou etapách. Bezprostředně po vyhlášení krizové situace jsme se snažili zformulovat obecná pedagogická doporučení pro své kolegy i pro sebe. Druhá etapa pak představuje konkretizaci plánování výuky přednášek předmětu základy didaktiky, který pro nás z důvodu velkého počtu studentů představoval největší výzvu. 


\subsection{Obecná pedagogická doporučení}

Při počátečním uvažování o situaci jsme hledali informace na stránkách osvědčených zdrojů informací o vysokoškolské výuce na zahraničních univerzitách ${ }^{3}$, českých univerzitních webech ${ }^{4}$, později i na stránkách MŠMT, věnovaných vysokoškolské výuce ${ }^{5}$. Univerzita Karlova uveřejnila přehled a porovnání nástrojů k online výuce, na tento krok v následujících týdnech navazovaly webináře a online setkávání pedagogů s příklady dobré praxe.

Představujeme naše shrnutí pedagogických doporučení k nouzovému vyučování (ERT), které jsme zpracovaly kolem 20. března. Týkají se proporcí výuky a návrhu konkrétních kroků jednoho z možných scénářů plánování řízeného samostudia a online výuky, který může mít řadu modifikací.

\subsection{Proporce výuky - forma}

Vstupní rozvaha vychází z proporcí asynchronní a synchronní výuky. Při asynchronní výuce jsou předem připraveny materiály (videa, prezentace, články), studenti pak mohou pracovat na zadaných úkolech sami nebo ve skupinách. Tento způsob výuky umožňuje časovou flexibilitu, a tím může zpř́stupnit vzdělávání více studentům. Materiály navíc mohou fungovat jako archiv. Studentům však může chybět sociální interakce a nemožnost pokládat otázky zvyšuje šanci nesprávného porozumění. Synchronní výuka se odehrává v reálném čase, dochází k zapojení studentů s důsledkem pocitu afiliace. Okamžitá možnost studentů získat odpovědi na své otázky snižuje riziko nedorozumění. Nevýhodou mohou být technické problémy (s připojením k internetu, mikrofonem apod.) a požadavek, aby vyučující a všichni studenti nalezli na výuku společný čas. Vyučující v ideálním případě realizuje kombinaci asynchronní a synchronní výuky.

3 Harvard University, Teach Remotely - https://teachremotely.harvard.edu/best-practices; Rijskuniversiteit Groningen, Online Teaching for staff - https://www.rug.nl/education/ online-teaching/; Carnegie Mellon University, Eberly Center, Preparing to Teach Online https://www.cmu.edu/canvas/teachingonline/.

4 ZČU v Plzni, Zajištění online výuky - https://czv.zcu.cz/pro-zajisteni-online-vyuky-vyuzijtepodporu-oddeleni-czv/; Masarykova Univerzita, Bezkontaktní online výuka - https://it.muni. cz/online-vyuka; Univerzita Karlova, Možnosti distanční výuky - https://cczv.cuni.cz/CCZV215.html.

5 MŠMT, Na dálku: Vysoké školy - https://nadalku.msmt.cz/cs/vysoke-skoly. 


\subsection{Proporce výuky - obsah a rozsah}

Klíčový je výběr učiva pro jednotlivé formy výuky. Pro výběr vhodného učiva pro přednášku a učiva pro řízené samostudium platí úvaha: Co se student může naučit sám, necht'se učí sám. Vedle požadavku na splnění cílů předmětu je zároveň třeba zvážit celkovou studijní zátěž pro studenta a nastavit flexibilnější podmínky plnění požadavků předmětu. $V$ případě přednášek je nereálné trvat na synchronních nebo předem natočených přednáškách v poměru 1:1 k původně rozvržené prezenční výuce. Jako vhodnější přístup se doporučuje tvorba kratší online přednášky nebo výkladu, doplněná dalšími aktivitami. V menších úsecích se učíme lépe, náš mozek dokáže snadněji zpracovávat a aplikovat nové informace. Zároveň se budeme potýkat s výběrem vhodného učiva pro přednášku a s tím, jak rozplánovat řízené samostudium.

\subsection{Kroky pro jednotlivá témata}

Proces distanční výuky jsme rozdělily do čtyř kroků, u každého kroku uvádíme příklady strategií, které podporují porozumění a zapamatování. Navrhujeme tři asynchronní kroky a jeden synchronní krok; návrh lze rozšiřovat nebo redukovat.

1. Studentská př́prava (asynchronní). Smyslem tohoto kroku je připravit podmínky pro stěžejní téma přednášky. Studenti mohou dostat za úkol studium odborného textu $\mathrm{z}$ učebnice nebo článku v přiměřeném rozsahu, analýzu kazuistiky, zhlédnutí videa, případně ověřovací test vstupních znalostí. Tuto př́pravu je vhodné zkontrolovat, e-learning umožňuje připravit automaticky vyhodnocovaný test, je možné zformulovat i otevřené otázky, např.: Shrňte základní princip fungování daného mechanismu. Jaké vidíte souvislosti mezi koncepty těchto dvou autorů? Co mají uvedené metody společného a $v$ čem se liší? Zakreslete pojmovou strukturu a pojmenujte vztahy mezi základními pojmy. Pokud jste něčemu v textu nerozuměli, uved'te to. Pro vypracování př́ípravy je vhodné studenty motivovat, napřr. předem daným systémem bodového ohodnocení, určitou mírou volitelnosti (Vyberte si tři otázky ze čtyř) a také tím, že si odpovědi prostudujeme a budeme na ně v pozdější online komunikaci reagovat.

2. Předem natočená přednáška (asynchronní). Obsah přednášky je vhodné zaměřit na klíčové základní učivo, obtížné pasáže a části, ve kterých studenti často chybují, modelovou ukázku toho, jak expert přemýšlí o dané problematice, jak ji analyzuje a řeší apod. Doporučené zásady přednášky: 
3. Struktura. Na začátku uvedeme základní body přednášky, ideálně v psané formě. Můžeme se pokusit i zformulovat konkrétní cíl z pohledu studenta, např. Na konci této přednášky objasníte proces X a uvedete tři př́lklady. Porovnáte dva technologické postupy z hlediska X. Strukturu je vhodné na konci přednášky zopakovat (znovu promítnout), upozornit na nejdůležitější body.

4. Vizualizace. „Obraz řekne víc než tisíc slov.“ Obrazový materiál může mít v přednášce motivující nebo ilustrační roli, grafická schémata podporují srozumitelnost a strukturované uvažování. Pokud užíváte PowerPoint, měl by být převážně obrazovou a grafickou podporou přednášky, nikoliv odrážkovým seznamem toho, co říkáte. V případě odvozování postupu je vhodnější výklad se zápisem na tabuli; hlídáme pozici kamery, abychom nestínili.

5. Aktivizace a pozornost. Našim cílem je vést studenty $\mathrm{k}$ porozumění a k přemýšlení nad daným učivem. Je dobré, pokud jsou studenti vedeni k pořizování vlastních poznámek, poskytování PowerPointu před přednáškou není vhodné, podklady poskytneme dodatečně. Studenty ale můžeme před přednáškou upozornit, aby si vytiskli nějaké grafické materiály (např. prázdná schémata) a do nich doplňovali informace při přednášce. Přibližně každých 10-15 minut uvedeme př́klad z praxe, otázku k přemýšlení (s dostatečným časem na odpověd') nebo dílčí shrnutí. Před naším závěrečným shrnutím můžeme vyzvat studenty, at' si sami zapíší (1-3) klíčové myšlenky přednášky.

6. Přednes. Videozáznam je prostředek, který může pomáhat zlepšovat naši verbální i neverbální komunikaci. Můžeme se soustředit na přiměřené tempo a srozumitelnost řeči, uměřená gesta mohou funkčně ilustrovat odborný obsah. Nervozitu nebo parazitická slova lze korigovat vědomým dýcháním a vzpř́ímeným postojem.

7. Online videokonference (synchronní). Tento krok je důležitý ze dvou důvodů: jednak umožňuje aktivní účast studentů a živou diskusi k vyjasňování problematických míst přednášky nebo k řízenému procvičování učiva, jednak supluje sociální kontakt, navozuje pocit normálnosti a osobního spojení. Pro online přednášku platí obdobné zásady, jakou jsou ty uvedené v bodě (2). Dále lze vést konzultace k obsahu, strukturovaný výukový rozhovor, volnější diskusi, sdílení a komentování různých dokumentů 
apod. Tuto část výuky je vhodné realizovat podle pravidelného rozvrhu výuky, obvykle v kratším časovém rozsahu. Je dobré reagovat na studentské vstupy z kroku (1), ocenit jejich práci, propojit odpovědi s přednáškou a př́padně vyjasnit, co nebylo zodpovězeno. Studenty motivujeme $\mathrm{k}$ účasti na videokonferenci hromadnými zprávami přes studijní systém nebo e-learning, kde uvedeme program a cíl videokonference, př́ípadně připojíme i osobní přání, aby se v daném čase aktivně zúčastnili. Zároveň je dobré nahrát záznam online přednášky pro ty, kteří se nemohou připojit v čase synchronní výuky.

8. Samostatná práce studentů a její hodnocení (asynchronní). Cílem této etapy je aplikace a samostatné procvičování nového učiva. V závěru online setkání mohou být zadány úkoly k samostatné práci. To může někomu připomínat středoškolskou výuku. Výzkumy vysokoškolské výuky ale přesvědčivě ukazují, že časté zadávání úkolů a zejména jejich průběžné hodnocení je faktor, který zásadně zvyšuje úspěšnost studentů ve studiu. Období zrušené kontaktní výuky může být rizikové pro studijní úspěšnost, proto tato fakta stojí za uvážení. Úkoly mohou být krátké a jednoduché, můžeme vytvořit i automaticky opravované didaktické testy, př́ipadně facilitovat vrstevnické hodnocení a sebehodnocení. Nebo můžeme nechat studenty, at' sestaví testové otázky, o kterých si myslí, že by se na zkoušce mohly objevit. Můžeme tak zjistit, zda mají studenti přiměřená očekávání ohledně typů otázek na zkoušku a materiálů, které se mají naučit. Otázky mohou být dále využity ve výuce.

\subsection{Plán nouzové distanční výuky (ERT) předmětu základy didaktiky}

Předmět základy didaktiky pro bakalářské studijní obory se zaměřením na vzdělávání společně vyučují autorky textu a jeden další vyučující. Naše pedagogická a obsahová východiska $\mathrm{k}$ výuce předmětu jsou zformulována v článku Didaktika obecné didaktiky (Duschinská \& High, 2019). Zastáváme myšlenku aktivního učení; je empiricky potvrzeno, že zvyšuje úspěšnost studentů (Freeman et al., 2014). Aktivizaci se snažíme aplikovat v prezenční výuce i ve velkých přednáškách (High \& Duschinská, 2020); otázkou bylo, jak se tento prrístup podaří dodržet v rámci ERT. Tento semestr je v kurzu zapsáno 259 studentů. Prezenčně se uskutečnila dvě setkání, což považujeme za velmi důležité, nebot' studující si mohli alespoň rámcově navyknout na styl výuky v předmětu a naši komunikaci. 
Z časových a kapacitních důvodů jsme se rozhodli v rámci přednášek naplánovat a realizovat pouze dva z výše uvedených kroků, tj. (1) studentskou přípravu a (3) synchronní videokonference, jejichž záznamy následně zpřístupníme. Na počátku byly velké obavy z neznámého, překonávaly jsme je desítkami hodin práce a ověřování, povzbudil nás výrok „Spoiler: It gets better with time"

\subsection{Jaké technické řešení zvolit?}

Sebelépe připravenou výuku může zhatit nevhodné technické řešení. Volba nástroje pro asynchronní výuku byla jednoduchá, využily jsme Moodle Learning Management System (LMS), který již řadu let využíváme pro online podporu všech prezenčních kurzů, zveřejňujeme zde studijní materiály a dobrovolné úkoly i pro tento předmět a studenti i vyučující jsou na tento LMS zvyklí. Součástí Moodle však není nástroj pro pořádání videokonferencí.

Univerzita Karlova nabídla akademickým pracovníkům tři nástroje pro videokonference ${ }^{7}$, další pak byly $\mathrm{v}$ doporučeních fakulty. To nás překvapilo, protože nám známé zahraniční univerzity svým učitelům doporučují vždy pouze jednu videokonferenční platformu, kterou podporují. Svobodu volby videokonferenčního nástroje jsme nakonec ocenili, ale bylo to vykoupeno enormní časovou zátěží, nebot' jsme postupně vyzkoušeli MS Teams, Skype, Google Meet, Adobe Connect a ZOOM. Stanovili jsme si požadavky, které obsahovaly jak technické, tak i pedagogické parametry systému: (a) možnost připojení až 250 lidí; (b) integrované nástroje pro interakci (chat, hlášení do diskuse, hlasování v anketě, možnost rozdělení do menších skupin); (c) dobrá kvalita obrazu a zvuku, (d) nízké nároky na kvalitu internetového připojení. Vybrali jsme ZOOM, jehož rozšířenou licenci poskytovala akademická sít' CESNET $^{8}$ a který dle našeho názoru nejlépe splňuje všechny čtyři požadavky. Z hlediska přístupu studentů má minimum bariér, přístup je přes aplikaci nebo webové rozhraní, funguje i na chytrém telefonu a ovládání je poměrně intuitivní. $V$ jednoduchém chatu lze posílat zprávy všem nebo jen jednotlivcům. Anketní otázky (polls) lze připravit předem, mohou být v anonymním

\footnotetext{
Schiano, B., \& Andersen, E. (2019). 8 Tips for Teaching Online. Dostupné z https://hbsp. harvard.edu/inspiring-minds/8-tips-for-teaching-online

7 Univerzita Karlova. (2020). Přehled nástrojů pro webináře. Dostupné z https://dl.cuni.cz/ prehled-nastroju-pro-webinare/

8 CESNET. (2020). Služby během pandemie COVID-19. Dostupné z https://www.cesnet.cz/ sluzby/covid19/
} 
režimu, vizualizaci výsledků ankety lze následně promítnout (a komentovat). Videokonferenci i chat lze zaznamenat. Vynikající je možnost malých samostatných diskusních skupin (tzv. breakout rooms), systém jich umožňuje otevř́t až 50, vyučující do nich mohou vstupovat nebo posílat zprávy. Záhy po výběru platformy jsme zjistili, že v médiích probíhá zkratkovitá diskuse o bezpečnostních rizicích platformy ZOOM, což nás vyděsilo. Dohledali a pročetli jsme původní texty a usoudili jsme, že hlavním rizikem je účast nepozvaných hostů, což nám vzhledem $\mathrm{k}$ veřejné povaze vysokoškolských přednášek nevadí. Sdružení CESNET později vydalo vlastní analýzu9 , uvádějící medializovaná bezpečnostní rizika na pravou míru.

\subsection{Obsah výuky}

$\mathrm{V}$ první řadě bylo nutno rozmyslet si, jaká témata budeme vyučovat asynchronně, jaká synchronně a jakým způsobem. Ze zbývajícího obsahu kurzu jsme pro samostudium vybrali témata jednodušší, spíše popisná a s dostatkem česky psané literatury. Zde pomohla služba Národní knihovny ${ }^{10}$ dočasným zpřístupněním vybraných publikací studentům vysokých škol prostřednictvím aplikace Kramerius. V e-learningu jsme ponechali dříve vypracované prezentace jako osnovu a aktualizovali jsme doporučenou literaturu. Pozornost jsme soustředili na čtyři témata, která považujeme za klíčová a u kterých vyžadujeme hlubší úroveň znalostí a porozumění. Jednalo se o dialogickou výuku, motivování žáků ve výuce, formativní hodnocení a podporu metakognice. Výuku těchto čtyř témat jsme naplánovali na osm týdnů. Vysoké školy se uzavřely od 11. března; zadání prvního úkolu jsme odeslali 28. března, první online přednáška byla 3. dubna, poslední 15 . května. Doba do zahájení ERT měla být kratší, ale nebylo v našich silách vše dříve naplánovat a vyzkoušet. Viz též ilustrativní výrok ze studentského hodnocení: „Výuka sice začala po delší odmlce, ale zato ze všech online výuk je nejpřipravenější. Systém je promyšlený a přednášky se mi líbí víc než v aule."

\section{Krok 1: Studentská příprava na výuku (asynchronní)}

Pět až sedm dní před videokonferencí studující dostali zadání dobrovolného úkolu $\mathrm{k}$ tématu přednášky (srovnej s flipped learning, Felder \& Brent, 2015). Studentům jsme vysvětlili, že přednáška bude navazovat na úkol,

\footnotetext{
9 CESNET. (2020). Vyjádření k aktuálním bezpečnostním otázkám ohledně platformy ZOOM. Dostupné z https://vidcon.cesnet.cz/cs/app/zoomsecurity

10 Národní digitální knihovna pro studenty VŠ. Dostupné z https://kramerius-vs.nkp.cz
} 
vypracování úkolu tedy zvýší efektivitu přednášky. U některých témat jsme se snažili o překonávání fragmentace poznatků propojením s již absolvovanými kurzy. Např. úkol k tématu motivace zněl:

(1) Proč se žáci chtějí učit? Uvažujte nad touto otázkou a zapište si alespoň čtyři důvody, můžete i více.

(2) Zopakujte si učivo z oblasti motivace, které jste se dozvěděli v předmětu úvod do psychologie, a pokuste se ke každému ze svých důvodů přiřadit teoretické zdůvodnění, které jste se dozvěděli z kurzu (stačí krátce).

(3) Pokud máte možnost, diskutujte nyní se spolužáky.

(4) Prostudujte si kapitolu Motivace z publikace Moderní vyučování (G. Petty, 2006, s. 40-55).

(5) Jako řešení úkolu vložte body (1) a (2), dále u bodů (3) a (4) stručně uved'te, co nového jste se dozvěděl/a.

Za každý odevzdaný dobrovolný úkoly studující mohou získat až $3 \%$, která se započítají do finálního hodnocení. Zpětná vazba k úkolům není individuální, ale hromadná na přednášce, kde prezentujeme shrnutí a ilustrativní odpovědi.

Krok 2: přednáška formou videokonference (synchronní, záznam je asynchronní)

Časový plán přednášky se řídí principy kognitivní psychologie. Přednáška je obvykle složena z tří nebo čtyř přibližně patnáctiminutových monologických bloků, které jsou proložené dvěma nebo třemi interaktivními bloky; vše zakončuje závěrečná diskuse (chat i mluvené příspěvky). Aktivizovat studenty lze několika způsoby i při videokonferenci, tyto aktivity řadíme $\mathrm{z}$ hlediska rostoucího počtu zapojených studentů, od nejpřístupnějších až po nejméně př́stupné: (1) anonymní anketa, tj. online hlasování s následnou analýzou odpovědí; (2) diskuse v tzv. breakout rooms (rozdělení studentů do malých skupinek, např. po čtyřech); (3) chat; (4) mluvené př́íspěvky v diskusi. Toto pořadí zavádění aktivizujících technik můžeme doporučit, protože vede k postupnému budování bezpečného prostředí pro studenty a zvyšuje jejich ochotu se aktivně zapojovat.

Chat považujeme z výborný nástroj synchronní výuky. Studující byli na začátku každé videokonference povzbuzeni, že do chatu mohou psát nejen otázky, ale i svoje komentáře, a to jak veřejně, tak mezi sebou, případně jen vyučujícím. Abychom prolomili počáteční bariéru, studenti byli požádáni, 
aby v prvních minutách napsali odpověd' na zadanou otázku (např. Co jste se v karanténě naučili nového?). Další využití chatu vidíme ve dvou způsobech: (a) Na napsané otázky a komentáře lze reagovat ústně, př́ípadně vyzvat někoho ze studujících, zda nechce komentáře upřesnit nebo doplnit. Pokud je na videokonferenci prrítomen kolega/kolegyně, naskýtá se druhá možnost, kdy přímo na otázky a komentáře $\mathrm{v}$ chatu může reagovat právě on/a $\mathrm{v}$ reálném čase. (b) V závěru přednášky jsou studující požádáni, aby do chatu napsali zpětnou vazbu $\mathrm{k}$ přednášce, často $\mathrm{v}$ této struktuře (kterou do chatu píšeme): zaprvé, co nejdůležitějšího jste se dnes dozvěděl/a; zadruhé, jaké otázky si odnášíte; zatřetí, jak hodnotíte dnešní online přednášku. Tato zpětná vazba slouží studujícím jako shrnutí, ale také nám vyučujícím.

\section{Průběžné ověřování plánu výuky}

Stanovený plán výuky jsme se snažili průběžně vyhodnocovat a modifikovat. $\mathrm{V}$ této části textu vycházíme ze čtyř zdrojů informací, které reflektují proběhlou ERT výuku: (a) záznamy chatu ze čtyř online přednášek, celkem 433 příspěvků; (b) vlastní anonymní evaluační šetření po první přednášce, 79 hodnotících výroků od 31 studentů; (c) anonymní anketa vedení fakulty, 27 hodnotících výroků; (d) záznamy průběžné písemné komunikace mezi oběma autorkami textu, e-mail a FB Messenger. Nyní stručně uvedeme nejdůležitější témata a ilustrativní výroky.

\subsection{Studentská př́prava na prednášky}

Dobrovolné úkoly byly studenty vesměs hodnoceny jako zajímavé, mnozí oceňovali návaznost přednášky i to, že se díky předem získaným informacím neostýchali zapojit i dotazy a komentáři:

[S1]: Vyhovovalo mi, že jsem si před přednáškou mohla zpracovat zadaný úkol, díky kterému jsem poté lépe chápala výklad.

[S2]: Př́íprava probíhá ve formě dobrovolných úkolů, ve kterých využíváme i odbornou literaturu. Následně je úkolu věnována pozornost na přednášce. Tento způsob mi naprosto vyhovuje, přednášky mě touto formou baví, komunikace s vyučujícími je také skvělá.

[S3]: Nevadí mi ani domácí př́íprava v podobě úkolů, člověk si to alespoň průběžně opakuje a přemýšlí nad danou látkou, o které se pak na přednášce hovoří, takže za mě jedině dobře, mám pak méně práce o zkouškovém. 


\subsection{Aktivizace}

Studenti ve zpětných vazbách oceňovali diskuzi nad úkoly, malé diskusní skupiny i chatové diskuze:

[S4]: ... tím dáváte šanci více proniknout do problematiky nám studentům, a také, že i my něco děláme a tím více se pak můžeme podílet/sdílet/diskutovat během přednášky samotné.

[S5]: Využívají prostředků jako rozdělení do skupin - myslím, že to funguje lépe, než kdybychom byli $\mathrm{v}$ posluchárně, protože jsme od ostatních naprosto izolovaní, máme klid. Také se ve skupině octneme s někým náhodným (ne s tím člověkem, který sedí vedle nás a jehož názory pravděpodobně již známe).

[S6]: Úkoly se diskutují, i v online přednášce podávají anketní otázky, dělí nás do skupin, kde mezi spolužáky diskutujeme o nějakém tématu. Videokonference jsou živé, zajímavé, vyučující rády vše a s ochotou vysvětlí.

\subsection{Tým vyučujících}

Vyučování $\mathrm{v}$ týmu fungovalo jak při plánování a přípravě, tak i při realizaci výuky, kdy každý vyučující mohl komentovat téma ze své odborné perspektivy. Pomáhalo také aktivizovat studenty, klást otázky v chatu a komentovat odpovědi nebo se účastnit malých diskusních skupin. $\mathrm{V}$ online výuce velké skupiny je důležitá i kolegiální výpomoc, například při řešení technických problémů nebo jako záloha při výpadku spojení.

[S7]: Jsou na přednáškách ve třech (pí Duschinská, pí High a p. Starý), takže se parádně doplňují.

[S8]: Pozitivum synchronní online výuky spatřuji $v$ možnosti studenta bezprostředně $\mathrm{k}$ tématu komunikovat $\mathrm{s}$ vyučujícím (i vyučujícího se studenty), požádat o doplnění nejasností.

\subsection{Kontakt s vyučujícími}

Výroky týkající se blízkosti a dobrého kontaktu vnímáme jako poměrně nečekané, vyskytly se však opakovaně:

[S9]: Přestože se jedná o distanční výuku přes aplikaci Zoom, je výuka efektivní, dokáže propojit jak klasickou přednášku s prezentací, tak možnost komunikace o daném tématu ve skupinkách studentů, hlasování. Kontakt s učitelem může být paradoxně větší. 
[S10]: Lepší atmosféra, větší zainteresovanost v domácím prostředí, než když jsme v obrovské aule, dáváme víc pozor, je to efektivnější.

\section{5 Účast na přednáškách}

Přednášky jsou nepovinné, v průběhu semestru se účast na pátečních prezenčních přednáškách pohybuje odhadem mezi 50-80 studenty. Prvních tři online přednášek se účastnilo 100-115 studentů, záznamy druhé a třetí přednášky mají 128 a 91 zhlédnutí (první přednášku se nepodařilo nahrát). Třetí přednáška se uskutečnila poslední den prodloužené výuky, tři týdny po původně plánovaném ukončení, zúčastnilo se jí cca 60 studentů a dalších 37 si prohlédlo záznam. $V$ našem př́padě byla účast na online přednáškách výrazně vyšší než na prezenční výuce.

\subsection{Pracovní zátěž vyučujících}

Plánování a realizace synchronní výuky jsou časově náročné aktivity. K těmto aktivitám se připojilo i čtení, bodové hodnocení a sumarizace odevzdaných dobrovolných úkolů. Úkoly byly záměrně formulovány jako otevřené a studenti psali zajímavá a dlouhá řešení. Po třetí online přednášce jsme do hodnocení úkolů zapojili dvě studentky oboru pedagogika z vyššího ročníku studia. To předpokládalo důvěru v jejich schopnosti, která má dva rozměry. Zaprvé, přesvědčily jsme se, že studentské asistentky jsou velmi schopné, jejich pomoc usnadnila naši práci a studující měli zpětnou vazbu o něco dříve než obvykle. Zároveň je možné, že tyto studentky budou pokračovat v doktorském studiu; v zahraničí tato pozice do jisté míry funguje při rozvíjení nadaných a motivovaných studujících v posledním ročníku. Reflexi této situace ilustrujeme kopií konverzace autorek z 14. 5. 2020 :

[KD]: Ahoj, [studentka] udělala shrnutí, za mě je to skvělé. Kdyžtak ji taky pls napiš... díky, K.

[RH]: Jé, to je moc pěkný. Šikovná studentka.

[KD]: A máme další téma do článku Pg orientace. Část „Co jsme objevily a chceme zachovat do budoucna"

[RH]: A zase to jde za aktivizací studentů. A tady je navíc dobré to, že to usnadní práci. A to není moc časté

[KD]: [...] Přesně! Tohle je win-win. Možná pak půjde na PhD. Nebo ne... Je to hodně o důvěre ve schopnosti studentů

[RH]: Jj, to mě taky napadlo - budování vztahů s nástupci/budoucími kolegy. Ale jsme zase u základu, že učitel musí mít nastavení mysli, že to ti studenti zvládnou 
[KD]: Pracovní název článku - Důvěřujme schopnostem studentů. A svým vlastním také!

[RH]: Vezmi si, že my to nastavení máme, a přesto nás př́ijemně překvapují.

[KD]: To je fakt. Pak se div, že se řeší hlavně kontrola.

[RH]: My nejsme zvyklí jim důvěřovat. Naopak očekáváme, že nás podvedou.

[KD]: A někteří nás skutečně podvedou... ale věřím, že ne většina

[RH]: Tohle období mohlo ukázat, že jim důvěřovat můžeme, protože oni se chtějí vzdělávat.

[KD]: [...] Moc hezky jsi to vystihla. Je to na téma Ownership of own learning.

\subsection{Srovnání prezenční a nouzové distanční výuky}

Srovnávání prezenční a nouzové distanční výuky se nedoporučuje (Hodges et al., 2020), ale studenti jej spontánně uváděli. Dozvídali jsme se, že online výuka může být i lepší, at' už $\mathrm{z}$ důvodu bližšího kontaktu s vyučujícím nebo lepší aktivizace:

„Výuka online probíhá bez problémů, a ještě je tam přidaná hodnota, můžeme dělat úkoly, o kterých se pak na přednášce bavíme a funguje to i při vysokém počtu studentů lépe než prezenčně."

Mnohokrát se objevily výpovědi, které tematizují pohodlí domova; studující psali o tom, že doma je dobrá atmosféra, nikdo je neobtěžuje povídáním, mohou si udělat čaj, pohodlně se usadit a poslouchat:

„Synchronní výuka formou videokonference mi připadala výborná, určitě se zapojím aktivněji než na prezenční výuce (komfort domova, všichni se navzájem dobře slyší, pozornost není narušena neukázněným chováním některých).“

Náš plán nouzové výuky se osvědčil jako funkční, průběžné modifikace se týkaly spíše dílčích záležitostí, např. složení malých diskusních skupin nebo posloupnosti forem aktivizace studentů. Po zhlédnutí záznamů vlastních přednášek si s odstupem uvědomujeme řadu nedostatků, především v časovém plánu a v návaznosti výkladových a aktivizujících bloků.

\section{Poznatky pro budoucnost, čemu nás naučila nouze}

Karanténa nám přinesla nové úkoly a povinnosti a zrychlení procesu př́pravy online výuky bylo jedním z důsledků. Některé dovednosti, které jsme při této neobvyklé zkušenosti získali, chceme využívat i v budoucnu. Jedná se 
především o dovednosti spojené s těmito pěti oblastmi: (a) aktivizace studujících a důvěra $v$ jejich schopnosti; (b) studentská př́íprava na přednášky; (c) týmové vyučování; (d) studentské asistentky; (e) online testování. Některé důležité prvky jsme nestihli připravit, ale víme, že je do budoucna chceme rozvíjet - především (f) strukturaci online modulů a (g) průběžné formativní hodnocení (navazujeme zde na náš původní plán čtyř kroků, představený ve druhé kapitole).

\subsection{Co jsme ověrili a chceme dále rozvíjet}

(a) Při vyšší aktivizaci studentů se ukázalo, že studující mají velký zájem o vzdělávání a jejich názory a myšlenky jsou leckdy velmi objevné. Díky různým typům aktivizace se navíc projevili i studenti, kteří by v aule aktivní nebyli, což nám, vyučujícím, působilo radost z práce.

(b) Z hlediska aktivizace studentů jsou úkoly zadávané před vlastní přednáškou (prvky flipped classroom) efektivní, což potvrzují nejen zahraniční zkušenosti z vysokoškolské výuky (Felder \& Brent, 2015), ale i naši studující. Klíčem k úspěchu je důvěra ve schopnosti studentů a zároveň vhodné nastavení parametrů vnější motivace, např. body za dobrovolné úkoly.

(c) Týmové vyučování se v minulých semestrech osvědčilo nejen pro nás, ale je efektivní i pro studenty (Cramer, 2010). Tandem se osvědčil jak v př́ípravě, tak při realizaci online přednášek, kdy jedna z nás vyučuje a druhá může reagovat na dotazy a komentáře studujících $v$ chatu, případně řešit technické problémy studujících. Oba učitelé v tandemu mohou zároveň komentovat danou problematiku ze své odborné perspektivy. Odborné vstupy máme částečně připraveny předem, částečně reagujeme př́mo na místě, což je autentické a také nás to baví. Do tandemu pedagožka-psycholožka se tento semestr připojil i náš kolega výzkumník. Toto týmové trio obohacuje výuku ještě více.

(d) Inspirovali jsme se u tzv. TAs (teaching assistents), běžných na některých zahraničních univerzitách, a zapojili jsme do výuky dvě tzv. studentské asistentky, které nám po vstupní instruktáži pomáhají s hodnocením a shrnováním studentských úkolů v e-learningu.

(e) Ověřili jsme závěrečnou zkoušku ve formě online testu v Moodle a tento způsob ověřování znalostí hodnotíme při daném počtu studentů jako 
vhodný. Plánujeme rozšiřování databáze otázek; prevenci podvádění vidíme v kladení otázek vyšší kognitivní náročnosti, což je v souladu s cíli předmětu.

\subsection{Co jsme nezvládli ověřit, ale vnímáme to pro budoucnost výuky jako důležité}

Strukturování online kurzu; základem online podpory výuky je přesné naplánování tří hierarchických úrovní: kurz - týden - krok. ${ }^{11}$ Na úrovni celého kurzu je východiskem precizní formulování výukových cílů, které jsou dále rozpracovány jako výsledky učení pro jednotlivá témata (týdny). V každém týdnu je pak připravena sada výukových materiálů $v$ jasně navazujících krocích, jasně je odlišeno základní učivo a doplňující materiály pro zájemce.

(g) Průběžné hodnocení souvisí s předchozím bodem. Jako součást každého tematického celku chceme připravit průběžnou autoevaluaci znalostí a porozumění, kde částečně automatizovaná zpětná vazba pomůže studentům nasměrovat a rozvíjet svoje učení.

Na závěr uvádíme výňatek konverzace autorek textu (21. 4. 2020):

[RH]: Zkušenost z korony doby: ted' už to nemůžu učit jako předtím. Pokud jim ty znalosti předáváme pasivně, tak strašně bereme nejenom jim, ale i nám jako vyučujícím.

[KD]: Funguje to krásně. A pro mě je to zatím strašná práce, asi než se to naučím takto dělat... např. ten úkol jsem připravovala a precizovala hodně hodin. A další čas bude čtení, opravování, shrnování... baví mě to, baví mě pak po tom učit, ale má to limity.

[RH]: Ano, strávím nad tím hromadu času. I jen připravit ty úkoly - jak píšeš, trvá hodiny. Ale zase př́ští rok už to bude lepší. Asi nebudu měnit úplně vše, nějaký základ zůstane. A takový pomvěd by pomohl hodně. Také mi z toho neustále vychází, že náš český systém - učitel vykládá, studující zapisují a po 12 týdnech je zkouška, je špatně. To, co děláme v didaktice - dáváme body za úkoly, to bych si představovala více. Musím říct, že [studenti] vyplňují úkoly skoro všichni. Kdo nestihne termín, posílá e-maily. Tady je vidět, že když se to nastaví jinak, tak že studenti pracují. Nejsou to ti leniví, co nechtějí nic dělat...

11 University of Groningen (2020). Structuring you online course. Dostupné z https://www.rug. $\mathrm{nl} /$ education/online-teaching/structuring-online-course/ 
Nouzová výuka nás naučila především intenzivní kolegiální spolupráci a větší důvěře schopnostem studentů i svým vlastním. Naší vstupní otázkou bylo, jak princip aktivizace studentů na velkých přednáškách dodržet v rámci ERT. Lze říci, že mimořádná situace nás dovedla nejen $\mathrm{k}$ jeho dodržení, ale i k rozvinutí. Výzvou do budoucna pak bude, jak tyto zkušenosti dále rozvíjet v prezenční i kombinované formě výuky.

\section{Literatura}

Cramer, E. D. (2010). Co-teaching. International Encyclopedia of Education, vol. 2. Elsevier Ltd.

Duschinská, K., \& High, R. (2019). Didaktika obecné didaktiky: Od deklarativní znalosti pojmů směrem k rozvoji didaktického myšlení. Pedagogika, 69(3), 316-332.

Felder, R. M., \& Brent, R. (2015). To flip or not to flip. Chemical Engineering Education. 49(3), 191-192.

Freeman, S., Eddy, S. L., McDonough, M., Smith, M. K., Okoroafor, N., Jordt, H., \& Wenderoth, M. P. (2014). Active learning increases student performance in science, engineering, and mathematics. PNAS Proceedings of the National Academy of Sciences of the United States of America, 111(23), 8410-8415.

High, R., \& Duschinská, K. (2020). How to Motivate Students in Large-enrollment Courses for Active-learning. Proceedings of the 6th International Conference on Higher Education Advances (HEAd'20), Universitat Politecnica de Valencia, Valencia.

Hodges, C., Moore, S., Lockee, B., Trust, T., \& Bond, A. (2020). The Difference between Emergency Remote Teaching and Online Learning. EDUCAUSE Review. Dostupné z https://ereducause. edu/articles/2020/3/the-difference-between-emergency-remote-teaching-and-onlinelearning

Petty, G. (2006). Moderní vyučování. Praha: Portál.

Skalková, J. (2007). Obecná didaktika: vyučovací proces, učivo a jeho výběr, metody, organizační formy vyučování. Praha: Grada.

\section{Autoři}

Ing. Karolina Duschinská, Ph.D., Univerzita Karlova, Pedagogická fakulta, Katedra pedagogiky, Magdalény Rettigové 4, 11000 Praha 1, e-mail: karolina.duschinska@pedf.cuni.cz

PhDr. Radka High, Ph.D., Univerzita Karlova, Pedagogická fakulta, Katedra psychologie, Myslíkova 7, 11000 Praha 1, e-mail: radka.high@pedf.cuni.cz 